\title{
Література
}

1. Антипова В. М. Компетентностный подход к организации дополнительного педагогического образования в университете / В. М. Антипова, К. Ю. Колесина, Г. А. Пахомова // Педагогика. - 2006. - №8. - С. 57-62. 2. Болонский процесс: поиск общности европейских систем высшего образования (проект TUNING) / под науч. ред. В. И. Байденко. - М. : Исследовательский центр проблем качества подготовки специалистов, 2006. - 211 с. 3. Буркова Л. В. Експериментальне дослідження ефективності інноваційної технології підготовки фахівців соціономічних професій у вищій школі [Електронний ресурс] / Л. В. Буркова // Теорія та методика управління освітою. - 2010. - Вип. 5.- Режим доступу до журн.: http:// tme.umo.edu.ua/docs/5/11burhes.pdf. 4. Глоссарий терминов рынка труда, разработки стандартов, образовательных программ и учебных планов. - Турин : Европейский фонд образования, 1997. - 160 c. 5. Драч I. I. Компетентнісний підхід до професійної підготовки техніків-геофізиків 3 ремонту та обслуговування устаткування [Електронний ресурс] / I. І. Драч, М. О. Сперкач // Теорія та методика управління освітою. - 2010.- Вип. 5.- Режим доступу до журн.: http://tme.umo.edu.ua/docs/5/11drarme.pdf. - Назва 3 екрану. 6. Зимняя И. А. Компетентностный подход. Каково его место в системе современных подходов к проблемам образования? (теоретико-методологический подход) / И. А. Зимняя // Высшее образование сегодня. - 2006. - №8.- С. 21-26. 7. Компетентностный подход [Электронный ресурс]// Глоссарий: сущность компетентностного подхода [Сайт]/ Алтайская академия экономики и права. - Режим доступа: http://www.aael.altai.ru/index/fictive/sajt/sistema_/mezhdunar/dokument/glossari/at_word _doc/736/ index.htm. 8. Сирмбард С. Р. Методические рекомендации по разработке моделей выпускников и проектированию учебных планов в высших учебных заведениях Кыргызской Республики на основе компетентностного подхода / С. Р. Сирмбард, А. Ф. Джаналиев, У. Фишер-Зуйков. - Бишкек : Кыргызский нац. ун-т, 2007. -57 с. 9. Стратегия модернизации общего образования. Материалы для разработчиков документов по модернизации общего образования / В. В. Башев [и др.]. - М. : ООО «Мир книги», 2001. - 104 с. 10. Субетто А. И. Онтология и эпистемология компетентностного подхода, классификация и квалиметрия компетенций / А. И. Субетто. - СПб.-М. : Исследовательский центр проблем качества подготовки специалистов, 2006 - 72 с. 11. Хуторской А. В. Ключевые компетенции как компонент личностно-ориентированной парадигмы образования / А. В. Хуторской // Народное образование. - 2003. - №2. - C. $58-64$. 12. Ялалов Ф. Г. Деятельностно-компетентностный подход к практикоориентированному образованию [Электронный ресурс] / Ф. Г. Ялалов // Интернетжурнал «Эйдос». - 2007. - 15 января. - Режим доступа к журн.: http://www.eidos.ru/journal/2007/0115-2.htm. - Загл. с экрана.

Тетяна Дороніна

\section{СУЧАСНІ ПІДХОДИ ДО ВИЗНАЧЕННЯ СУТНОСТІ ТА СТРУКТУРИ ОСВІТНЬОГО СЕРЕДОВИЩА}

Дороніна Т. О. Сучасні підходи до визначення сутності та структури освітнього середовища.

У статті проаналізовано стан проблеми освітнього середовища у вітчизняній і зарубіжній педагогіці, окреслено структурні компоненти освітнього середовища, охарактеризовано сучасні підходи до визначення поняття «освітнє середовище».

Ключові слова: освітне середовище, структура освітнього середовища, педагогічний вплив, освіта. 
Доронина Т. А. Современные подходы к определению сущности и структуры образовательной среды.

В статье проанализировано состояние проблемы образовательной среды в отечественной и зарубежной педагогике, очерчены структурные компоненты образовательной среды, охарактеризованы современные подходы к определению понятия «образовательная среда».

Ключевые слова: образовательная среда, структура среды образования, педагогическое влияние, образование.

Doronina T. O. Current approaches to determining the nature and structure of the educational environment.

The article analyses present condition of educational environment problem research of national and foreign pedagogy, discusses the components of the educational environment, the modern approaches to the definition of concept «educational environment» are described.

Key words: educational environment, pedagogical impact, education.

Тенденції розвитку вітчизняної освіти характеризуються посиленням вимог до освітнього рівня випускників навчальних закладів різного освітнього рівня задля їхньої успішної адаптації в умовах стрімкої зміни соціально-культурного оточення й успішної життєвої самореалізації. Науково-педагогічне товариство досить уважно ставиться до питань, пов'язаних із проблемою створення найбільш сприятливого для навчання оточення. Як зазначають дослідники, «освітне середовище становить основу життєдіяльності будь-якої освітньої установи» $[1$, с. 6]. Тому вивчення впливу освітнього середовища на процес формування особистості учнів / учениць, студентів/ студенток не втрачає своєї актуальності в сучасному науковопедагогічному дискурсі.

Різноаспектному висвітленню сутності поняття «освітнє середовище» (далі OC), дослідженню окремих його варіантів, розкриттю прийомів і технологій проектування та конструювання ОС, впливу ОС на формування особистих якостей суб'єктів навчально-виховного процесу присвячено роботи багатьох вітчизняних та зарубіжних науковців: І. Арендачук, К. Беркімаєва, Т. Білоочко, В. Бутенко, І. Габа, О. Гора, Т. Гущіна, С. Дерябо, 3. Количева, О. Малахова, О. Мариновська, Т. Марченко, В. Пашков, В. Слободчиков, І. Чернецький, О. Швидка, В. Ясвін та ін. Слід також зазначити, що поняття ОС часто розглядається науковцями в зіставленні 3 поняттям «освітнього простору» (Н. Василенко, В. Вертугін, Г. Водяненко, О. Гор, С. Кривих, В. Пашков та ін.), що певним чином ускладнює визначення структурних компонентів власне ОС, а, відповідно, впливає на процес його моделювання задля досягнення певної педагогічної мети.

Попри високий науковий інтерес до феномену ОС, слід задзначити, що це поняття в науковому дискурсі має безліч конотативних варіантів: «інформаційноосвітне середовище», «культурно-освітнє середовище», «адаптативне освітнє середовище», «гуманістично зорієнтоване освітне середовище», «особистісно зорієнтоване освітнє середовище» тощо, що свідчить про неоднозначність наукової дефініції ОС та можливість її варіативності.

Mema cmammi. Відповідно до визначеної проблеми вважаємо за необхідне встановити сутність поняття «освітне середовище» шляхом висвітлення сучасних наукових підходів до проблеми та узагальнення поглядів науковців щодо структури ОС. Поділяємо позицію Т. Гущиної стосовно важливості «чіткого уявлення про 
структурні одиниці освітнього середовища для його проектування в контексті організації системи можливостей для задоволення всього комплексу потреб та реалізації особистісних цінностей усіх суб'єктів освітнього процесу» [6, с. 188]. Утім серед сучасних науковців відсутня єдність думок щодо цих компонентів, що ускладнює процес проектування та практичного втілення певної (відповідно до умов) моделі ОС.

Є низка визначень ОС. У контексті нашого дослідження визначення категорії як теоретичного поняття потребує конкретизації іiі двох складників: «освіта» та «середовище».

Ми дотримуємося підходу, запропонованого В. Ясвіним, який розглядає освіту як «спеціально організований цілеспрямований процес формування особистості за визначеним взірцем» $[14$, с. 14$]$.

Тоді як середовище - поняття більш загальне та залучає широкий науковоприродничий контекст, але «категоріально скрізь має те саме навантаження: середовище $\epsilon$ те, у чому виявляється активність явища, що цікавить нас» [8, с. 183]. Також слід зазначити, що передовсім науковці визначають концептуальний характер теорії середовища (В. Пашков) та вказують, що в найбільш «загальному тлумаченні «середовище» розуміється як оточення» [6, с. 187].

У зв'язку 3 певним ототожненням понять «освітнє середовище» та «освітній простір» деякими сучасними науковцями вважаємо за необхідне зробити уточнення (більш докладно про це у[7]). Ми дотримуємося поглядів тих науковців, які вважають поняття ОС підпорядкованим поняттю освітнього простору, тому «освітнє середовище може розглядатися як функціональна компонента освітнього простору, що є вмістилищем для останніх» [12, с. 139]. Отже, досліджувані поняття можна зіставити в категоріях: зміст / форма, локальне / глобальне, динамічне / статичне. Суттєва відмінність понять «освітнє середовище» і «освітній простір» полягає в обов'язковій присутності (дії/ взаємодії) в освітньому середовищі суб'єктів освітнього процесу. Тому ми дотримуємося позиції тих науковців, які вважають, що спільним у поняттях «освітній простір» та «освітнє середовище» $€$ «спрямованість на завдання освіти, обидва є оточенням, зовнішнім щодо суб'єкта освітнього процесу. Середовище передбачає заглибленість у нього, сьогохвилинне або часте використання потоку інформації для цілей зміни та вдосконалення людського «Я». Натомість освітній простір значною мірою передбачає не заглибленість, а присутність, простір виконує свої функції в моменти більш критичні чи вирішальні для майбутнього, що пов'язані з доленосним вибором» [13].

Також уважаємо за необхідне наголосити на важливості розмежування понять «освітнє середовище» та «середовище навчання» («навчальне середовище»), при цьому якщо освітнє середовище виникає як стихійно, так і організовано, то навчальне середовище - цілеспрямовано організується» [12, с. 139]. Отже, виникає потреба уточнення поняття навчальне середовище. «Навчальне середовище - це штучно побудована система, структура і складники якої створюють необхідні умови для досягнення цілей навчально-виховного процесу» [2, с. 6]. Відповідно до такого визначення науковець виокремлює підсистеми навчального середовища: цільова аудиторія, змістовно-інформаційний складник, учительський складник, освітній мікросоціум, система засобів навчання, технологічний складник, навчальні приміщення [2, с.8]. Власне у такому тлумаченні складники навчального середовища практично збігаються зі складниками середовища освітнього, що актуалізує питання контамінації понять «освітнє середовище» та «навчальне середовище», прикладом чого може слугувати цікава робота Л. Рибалко «Сучасні 
підходи до визначення поняття «навчальне середовище»» [9], у якій незроблені уточнення щодо розмежування означених вище понять спонукали автора (Л. Рибалко) до уведення поняття «освітнє навчальне середовище».

Узагальнений погляд на напрацювання сучасних науковців із питань ОС дозволяє констатувати, що ОС тлумачиться по-різному, а саме:

- функціонування конкретної освітньої установи (А. Веряєв, В. Козирев, I. Шалаєв), системний продукт взаємодії освітнього простору, управління освітою, місця освіти та суб'єкта освітнього середовища (В. Слободчиков);

- система «впливів і умов формування особистості, а також можливостей задля іiі розвитку, які містяться в соціальному і просторово-предметному оточенні» (В. Ясвін, І. Арендачук); «сукупність усіх можливостей навчання і розвитку особистості» (С. Дерябо);

- «функціональне і просторове об'єднання суб'єктів освіти, між якими встановлюються тісні різнопланові групові взаємозв'язки, і може розглядатися як модель соціокультурного простору, в якому відбувається становлення особистості» (О. Гора); форма єдності людей, «яка утворюється в результаті їх спільної діяльності в освіті» (І. Габа).

I. Арендачук звертає увагу на те, що саме ОC «забезпечує педагогічні умови врівноваження досвіду взаємодії учнів із зовнішнім середовищем та внутрішнім середовищем їхнього розвитку» [1], тобто науковець виокремлює регулятивну функцію ОС. До цієї функції Т. Гущина [6] додає функції розвитку, відбору цінностей, функцію безпеки та фасилітації, номінуючи їх ключовими.

У розгляді ОС як педагогічної категорії спираємося на визначення О. Савенкова, згідно з яким ОС - «система педагогічних та психологічних умов, впливів, які створюють можливість для розкриття наявних та ще не виявлених здібностей та особистісних особливостей учнів» [10, с. 5].

Слідом за сучасними науковцями (І. Габа, Т. Гущина, В. Панов, О. Савенков, I. Чернецький та ін.), унаочнимо виокремлені сучасною педагогікою структурні компоненти ОС на рис. 1.

За певної семантичної подібності виокремлених компонентів очевидно, що структуру ОС складають такі чинники:

- просторово-предметний / матеріальний («об’єктивне буття матеріальних предметів» (I. Чернецький); матеріальні засоби - приміщення (архітектура будівлі, дизайн інтер'єру, розмір і простір аудиторних приміщень (Г. Ковальов, В. Ясвін), пристрої, устаткування, прилади, носії інформації, прилади для іiі опрацювання, особлива атрибутика навчальної ситуації тощо; символічний простір: герб, гімн, традиції («просторово-семантичний» (І. Габа);

- навчально-методичний / комунікаційно-організаційний («джерела асимільованої інформації» (І. Чернецький); форми та технології передачі інформації, ๗ii впорядкування та виокремлення; структура діяльності, стиль викладання і характер контролю, кооперативні або конкурентні форми навчання, зміст програм навчання (традиційність, консерватизм, гнучкість («програма навчання» (Г. Ковальов); правила внутрішнього розпорядку, статут навчального закладу, правила особистої та суспільної безпеки («інформаційний» (Е. Климов); зміст освітнього процесу, оволодіння учнем способами дії та організація навчання («психодидактичний» (В. Ясвін); концепції навчання та виховання, форми і методи організації навчання («змістовно-методичний» (І. Габа); 
- соиіально-особистісний («суб'єкти пізнання» (І. Чернецький) - суспільні запити, мотиви, потреби; особистісні особливості та успішність, зміна персонального та міжособистісного простору, розподілення статусів та ролей, статево-вікові особливості студентів та викладачів (Г. Ковальов - «людський чинник»); культура, досвід, спосіб життя оточуючих («соціально-культурний» (Є. Климов); тип культури та форма спільності вчителя / учня (В. Ясвін).

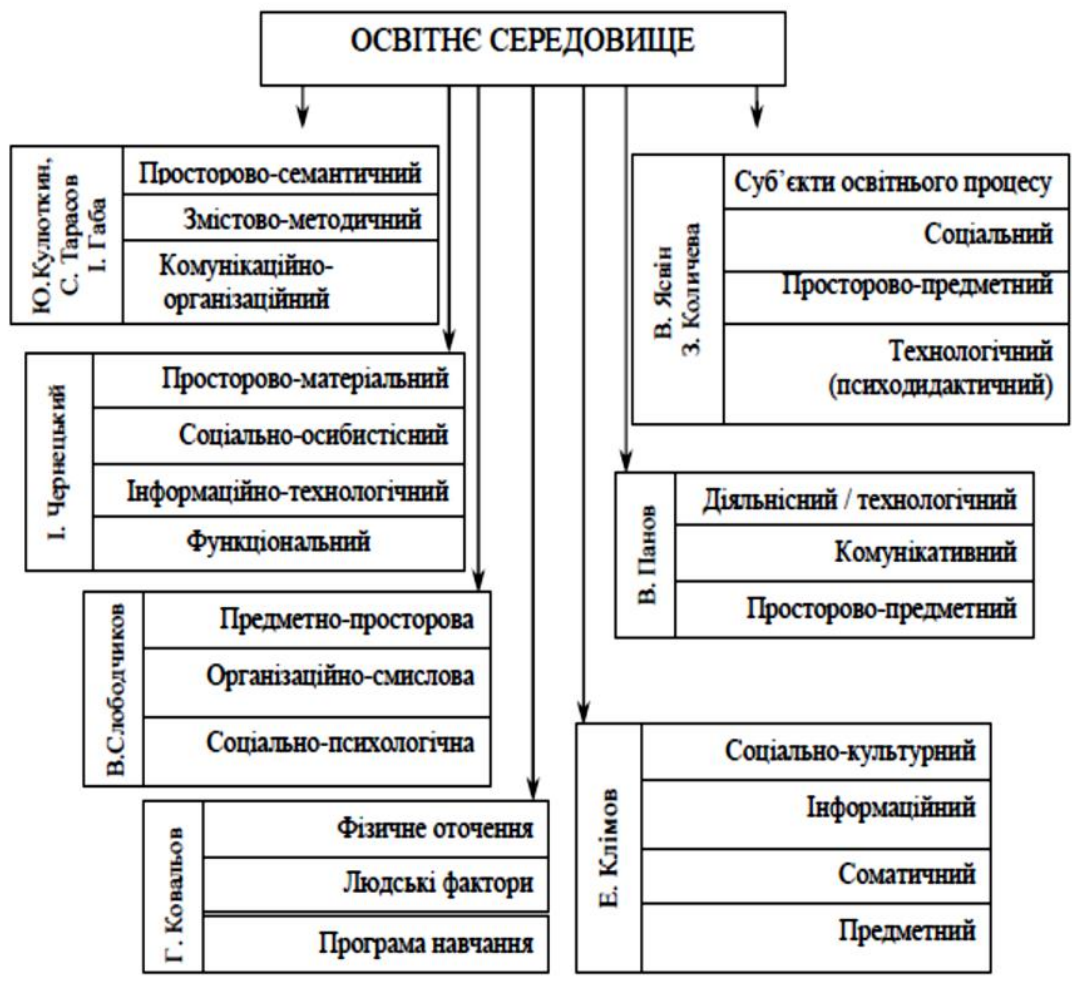

Рис. 1. Структурні компоненти освітнього середовища: сучасні наукові підходи

Об'єднання соціального та особистісного компонентів нам видається надзвичайно важливим. Спроби такого роду спостерігаємо в науковців, які виокремлюють низку підструктур кожного компонента. Показовим у цьому аспекті $\epsilon$ робота О. Гори, який у соціальному компоненті виокремлює «комплекс соціально орієнтованих потреб (тут і далі курсив наш. - Т.Д.) суб'єктів освітнього середовища, їх соціальних взаємодій та взаємовпливів; мотиваційний компонент формування в учасників середовища сукупності спонукань та внутрішніх переконань, що регулюють процес професійного зростання майбутнього спеціаліста; креативний компонент - творчість як чинник позитивного розвитку особистості; рефлексивний компонент - усвідомлення значущості національних налаштувань та запорука їх використання у професійній діяльності; аксіологічний 
компонент - формування системи особистісно значущих цінностей; інтегративний компонент - об'єднання попередніх компонентів у складну систему впливу на особистість» [5, с. 99].

Співвіднесення визначених вище компонентів подано на рис. 2.

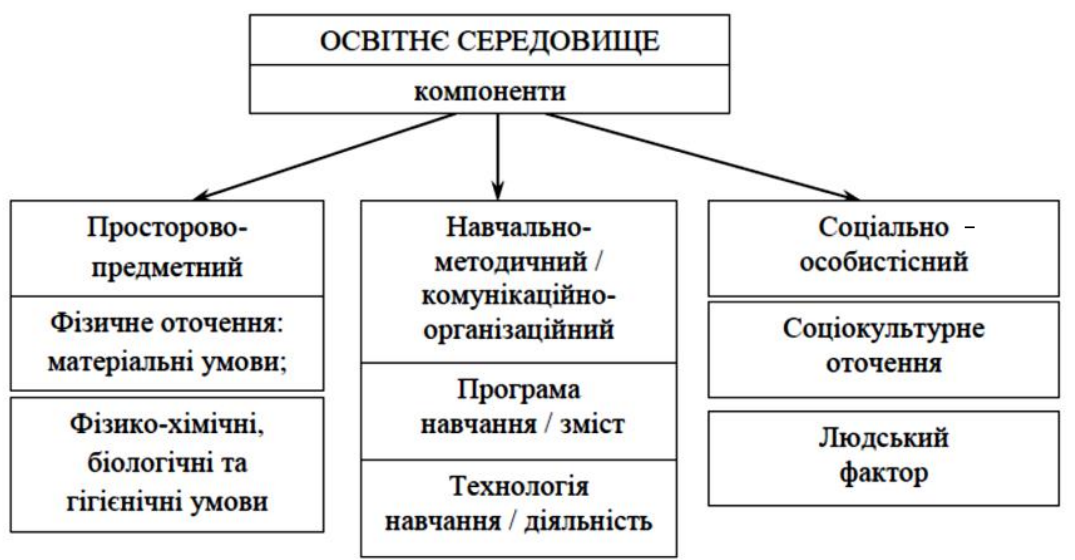

\section{Рис. 2. Структура освітнього середовищуа}

Освітнє середовище як «інтегрована багатокомпонентна система, компоненти якої відповідають навчальній, позанавчальній, науково-дослідницькій діяльності, вимірюванню, контролю та оцінці результатів навчання, діяльності з управління навчальним закладом», якій «притаманна максимальна варіативність, що забезпечує диференціацію всіх можливих користувачів» [2], якщо набуває ознак «штучно побудованої системи», перетворюється на середовище навчальне. На нашу думку, власне навчальне середовище і стає педагогічною системою в тому розумінні, у якому подана К. Беркамаєвим: «...сукупність таких взаємопов’язаних компонентів, як цілі: освіти, суб'єкти педагогічного процесу.., зміст освіти.., методи та форми педагогічного процесу та матеріальна база (засоби)» [2].

Окрім того, І. Габа підкреслює необхідність розмежування понять «розвивальне, особистісно зорієнтоване освітнє середовище», «адаптивне освітнє середовище» та «безбар'єрне освітнє середовище» 3 позиції «характеру середовищних впливів - наскільки вони мають розвивальний ефект, ураховують різноманітні потреби та інтереси особистості, сприяють іiі життєвому самовизначенню та самореалізації» [4, с. 29]. Отже, додавання певної атрибутивної ознаки до поняття ОС повинно містити вказівки на мету та засіб реалізації педагогічних цілей. Так, виникає потреба у виокремленні понять «освітнє середовище» та «педагогічне середовище»: «Різні поняття - педагогічне середовище, освітнє середовище - мають те загальне, що в них $є$ вказівка на якусь актуальну можливість для суб'єкта виявити діяльність відповідної якості педагогічну або освітню» [8, с. 189]. Отже, поняття ОС може бути розширене завдяки конкретизації власне педагогічних цілей здійснення навчально-виховного процесу. 
Актуалізація проблеми сутності освітнього середовища пов'язана 3 необхідністю побудови ефективної моделі функціонування освіти, яка створювала б умови та надавала можливості суб'єктам освітнього процесу для здобуття якісної освіти, розвитку та самореалізації. Стан розвитку сучасних досліджень проблеми освітнього середовища дозволяє не лише констатувати наявність низки теоретичних лакун попри значну увагу науковців до виокремленої проблеми, а й появу наукових рекомендацій стосовно практичного покращення ситуації. Позитивним прикладом такої роботи можемо вважати дослідження науковців під керівництвом О. Савенкова (Інститут педагогіки і психології освіти, «Московський міський педагогічний університет»), які вивчають проблему проектування предметнопросторового компонента (тобто одного складника) освітнього середовища. Своє завдання дослідники формулюють так: «...розробити теоретичні підходи та методику оцінки ступеня відповідності проекту шкільної будови, а також будови дитячого садка завданням реалізації сучасних педагогічних ідей і технологій» [11].

Зважаючи на значення освітнього середовища для навчання, виховання та розвитку особистості, нагальними залишаються питання з’ясування функцій освітнього середовища, розроблення методів його проектування та оцінки (експертизи). Тому подальше дослідження структури освітнього середовища із можливим виокремленням підструктур, безперечно, сприятиме успішності навчально-виховного процесу.

\section{Література}

1. Арендачук И. В. Образовательная среда вуза как фактор психологопедагогических рисков [Электронный ресурс] / И. В. Арендачук // Материалы VII интернет-конференции «Образование в современном мире»: современные парадигмы открытого образовательного пространства. - Саратов. - Режим доступа : http:/www.sgu.ru/files/nodes/77385/Arendachuk.pdf. 2. Беркимбаев К. М. Педагогические аспекты создания информационно-образовательной среды [Электронный ресурс] // К. М. Беркимбаев, Г. П. Мейрбекова, К. Б. Халилаева. - Режим доступа : http://www.rusnauka.com/10_NPE_2011/Pedagogica/2_83051.doc.htm. 3. Биков В. Ю. Теоретико-методологічні засади моделювання навчального середовища сучасних педагогічних систем / В. Ю. Биков // Інформаційні технології і засоби навчання: зб. наук. праць / за ред. В. Ю. Бикова, Ю. О. Жука; Інститут засобів навчання АПН України. - К. : Атака, 2005. - С. 5-15. 4. Габа І. М. Освітнє середовище: соціальнопсихологічна парадигма / I. М. Габа // Актуальні проблеми психології. - 2010. Т.7. - Вип. 22. - С. 27-31. 5. Гора О. В. Освітнє середовище як фактор формування національної ідентичності студентів вищих навчальних закладів/ О.В.Гора // Витоки педагогічної майстерності. - 2011. - Вип. 8. - Ч. 1. - С.97-101. 6. Гущина Т. Н. Педагогическая сущность феномена «образовательная среда»: по материалам исследования / Т. Н. Гущина // Общество. Среда. Развитие (Terra Humana). - 2011. - № 4. - C. 187-190. 7. Дороніна Т. О. Контамінація понять «освітній простір» та «освітнє середовище» в сучасному науково-педагогічному дискурсі / Т. О. Дороніна // Педагогіка вищої та середньої школи. - 2013. - Вип. 39. С. 177-184. 8. Пашков В. В. Освітнє середовище в системі післядипломної педагогічної освіти: методологічний аспект / В. В. Пашков // Гуманітарний вісник ЗДІА - 2012. - № 50. - С. 182-192. 9. Рибалко Л. М. Сучасні підходи до визначення поняття «навчальне середовище» / Л. М. Рибалко // Педагогічні технології. - 2010. № 5 (96). - С. 41-44. 10. Савенков А. И. Образовательная среда / А. И. Савенков // Школьный психолог. - 2008. - № 19. - С. 4-5. 11. Савенков А. И. Предметнопространственная среда как фактор развития личности ребенка [Электронный 
ресурс] / А. И. Савенков // Национальная Ассоциация Игрушечников России : [сайт]. - М. , 2007. - Режим доступа : http://www.rnta.ru/Presentation/Savenkov.pdf. 12. Чернецький I. C. Проектування навчальних середовищ на основі фрактальних властивостей їх складових / I. С. Чернецький // Вісник Черкаського університету. 2012. - № 13 (226). - С. 138-143. 13. Шалаев И. К. От образовательных сред к образовательному пространству: понятие, формирование, свойства [Электронный ресурс] / И. К. Шалаев, А. А. Веряев // Педагог. - 1998. - № 4. - Режим доступа : http://www.uni-altai.ru/Journal/pedagog/pedagog_4/articl_1.html.

14. Ясвин В. Образовательная среда: от моделирования к проектированию / В. Ясвин. М. : Смысл, 2001. - 365 с.

УДК 372.878

Богдана Жорняк

\section{ДИДАКТИКА ФОРМУВАННЯ ТВОРЧОЇ ОСОБИСТОСТІ ЗАСОБАМИ МУЗИЧНОГО МИСТЕЦТВА}

Жорняк Б. С. Дидактика формування творчої особистості засобами музичного мистецтва.

У статті висвітлено актуальну проблему формування творчої особистості молодшого школяра засобами музичного виховання шляхом використання різних видів музичної діяльності; запропоновано методику їх застосування у практичній діяльності сучасного вчителя музики; визначено шляхи та перспективи розв'язання окресленої проблеми.

Ключові слова: дидактична спрямованість уроку, дитяча музична творчість, музична імпровізація, музично-слухові уявлення, музично-творче мислення, творча особистість.

Жорняк Б. Е. Дидактика формирования творческой личности средствами музыкального искусства.

Статья раскрывает актуальную проблему формирования творческой личности младшего школьника средствами музыкального воспитания путем использования разных видов музыкальной деятельности; предлагается методика их применения в практической деятельности современного учителя музыки; определены пути и перспективы решения данной проблемы.

Ключевые слова: дидактическая направленность урока, детское музыкальное творчество, музыкальная импровизация, музыкально-слуховые представления, музыкально-творческое мышление, творческая личность.

Jhorniak B. Eug. Didactics of forming the creative personality by means of musical education.

The article covers the current aspects of forming the creative personality of younger pupils by means of musical education using kinds of musical activities, the technique of their application in practice music teacher, ways and prospects of the solution of this problem are defined.

Key words: didactic direction of the lesson, children's musical creativity, musical improvisation, audio-music imagination, creative music thinking, creative personality.

Нині інтерес педагогічної громадськості до названої проблеми зумовлений новою освітянською парадигмою, яка спрямовує навчально-виховний процес у 